Available online on 15.07.2020 at http://jddtonline.info
Open Access to Pharmaceutical and Medical Research
und 2011-18, publisher and licensee JDDT, This is an Open Access article which permits
unrestricted non-commercial use, provided the original work is properly cited

Open Access

Research Article

\title{
Comparison of Clinical, Biological and Evolutionary Characteristics between Childhood Acute Lymphoblastic and Myeloid Leukemia in Western Algeria, from 2016 to 2018
}

\author{
Sara Khedidja BEGHDOUD ${ }^{1}$, Chahrazed YOUCEF², Mustapha DIAF ${ }^{3 *}$, Amaria BOUMEDANE ${ }^{4}$ \\ 1. Department of Biology, Faculty of Natural and Life Sciences, Djillali Liabes University, Sidi-bel-Abbes, Algeria \\ 2. Department of Biology, Faculty of Natural and Life Sciences, Djillali Liabes University, Sidi-bel-Abbes, Algeria \\ 3. Department of Biology, Faculty of Natural and Life Sciences, Djillali Liabes University, Sidi-bel-Abbes, Algeria \\ 4. Centre Anti Cancer Emir Abdelkader CEA ORAN, Algeria
}

\begin{abstract}
Background and Objectives: Haematological malignancies account for approximately $40 \%$ of all cancers by the age of 15 years. Acute leukaemia (AL) account for one-third of childhood cancer cases; consisting of Acute Lymphoblastic Leukaemia (ALL) and Acute Myeloid Leukaemia (AML). The aim of this work is to describe the epidemiological, clinical, biological and evolutionary characteristics of children with acute leukaemia in the western and south-western region of Algeria.

Patients and Methods: A three-year retrospective study was undergone from January 2016 to December 2018 on children with acute leukaemia. The study was conducted at the paediatric oncology department of the anti-cancer -Emir AEK- of Missreghine in Oran.

Results: During this period, we identified 135 cases of diagnosed AL. The sex ratio M/F was 1.1. The "two to five-year" age group was the most affected. The prevalence of ALL, AML, and biphenotypic acute leukaemia (BAL) was $60.45 \%$, 23.88\%, and $15.57 \%$, respectively. The clinical signs were mainly presented by the tumour syndrome dominated by the presence of lymphadenopathy (63\%) and splenomegaly (56.3\%). The most frequent abnormal blood abnormalities were anaemia (66.66\% in ALL and 28.14\% in AML), thrombocytopenia (75.9\% in ALL and 24.4\% in AML) and leukocytosis (76.3\% ALL and 23.7\% AML).
\end{abstract}

Conclusion: Paediatric acute leukaemia is a real public health problem that requires special care and attention. This management must involve all epidemiological, clinical and biological aspects for this highly sensitive age group.

Keywords: Acute Leukaemia, Children, Epidemiology, Acute Lymphoblastic Leukaemia, Acute Myeloid Leukaemia.

Article Info: Received 08 April 2020; Review Completed 16 June 2020; Accepted 21 June 2020; Available online 15 July 2020

Cite this article as:

Beghdoud SK, Youcef C, Diaf M, Boumedane A, Comparison of Clinical, Biological and Evolutionary Characteristics between Childhood Acute Lymphoblastic and Myeloid Leukemia in Western Algeria, from 2016 to 2018, Journal of Drug Delivery and Therapeutics. 2020; 10(4):1-7 http://dx.doi.org/10.22270/jddt.v10i4.4202

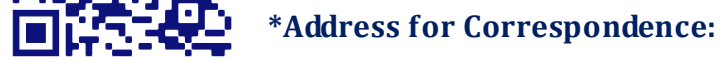

Dr. DIAF Mustapha. M.Sc. PhD. Department of Biology, Faculty of Natural and Life Sciences, Djillali LIABES University, PO. BOX 89, Sidi-BelAbbes 22000, Algeria,

\section{INTRODUCTION}

Haematological malignancies account for about $40 \%$ of all cancers by the age of 15 . Acute leukaemia remains the most common malignant tumour in children and represents onethird of paediatric cancers. ${ }^{1,} 2$ In Europe and the US, AL accounts for $80 \%$ of leukaemia and about $35 \%$ of childhood cancers. $^{3}$ Acute leukaemia are a group of hematologic disorders characterized by malignant proliferation and accumulation of a large number of clonal modularly precursors (blasts) of blood lines, blocked at a specific stage ISSN: 2250-1177 of differentiation that are found in the marrow, blood and sometimes other tissues. Depending on the line concerned, they are subdivided into acute myeloid leukaemia (AML) and acute lymphoblastic leukaemia (ALL). ${ }^{4}$ In children, $80 \%$ of acute leukaemia is called lymphoid or lymphoblastic (ALL). Of these cases, $80 \%$ are LALs of line B (affecting the development of B lymphocytes), called common. ${ }^{5}$ AML is relatively rare in childhood, accounting for $15 \%$ to $20 \%$ of $\mathrm{AL}$, but the most prevalent among adults. ${ }^{6}$ Epidemiological studies of acute childhood leukaemia have examined risk 
factors, including genetic, infectious and environmental factors. The majority is idiopathic: no identified cause. ${ }^{7,8}$ The clinical presentation of acute leukaemia results from infiltration of bone marrow or extramedullary sites by explosions. As a result, the first symptoms may be due to the presence of anaemia, neutropenia or thrombocytopenia. All tissues and organs can be affected, including ganglia, spleen and liver. ${ }^{9}$

Since these first descriptions, the diagnosis of ALL and AML is made on cytological and immunological criteria of bone marrow blasts. The contributions of immunophenotyping, cytogenetics and finally molecular biology have made it possible to describe more and more AL entities from one patient to another. ${ }^{10,11}$

The therapy differs considerably depending on the type of leukaemia developed in the child. It is risk-based optimizes the healing potential while minimizing risks and side effects. All acute leukaemias are treated with chemotherapy, but the treatment can be adapted, more intensive, for the most serious forms with sometimes a bone marrow transplant. 5 The aim of this work is to describe the epidemiological, clinical, biological and evolutionary characteristics of children with acute leukaemia in the western and southwestern region of Algeria, in the service of paediatric oncology of the anti-cancer centre -Emir AEK- Misserghine in Oran, north western Algeria.

\section{METHODS}

\section{Objectives of the study}

The objective of this study is to describe the clinical, biological and evolutionary characteristics of children with acute leukaemia in the West and South-West of Algeria.

\section{Type of study}

The study that we conducted is a retrospective descriptive and cross-sectional study, involving 135 files of patients who were treated for acute leukaemia in the Paediatric Oncology Department of the anti-cancer centre -Emir AEK- Misseghine in Oran, during the period from January 2016 to December 2018. The processing of the files covered duration of 3 months, from February 2019 to May 2019.

\section{Characterization of the population}

Our work is carried out on a population included all the patients aged 1 month to 16 years, of both sexes suffering from acute leukaemia, and coming from several regions of West and Southwest Algeria (Oran, Sidi-Bel-Abbes, Chlef, Bechar, Adrar, Ain Timouchent, El Bayadh, Mascara, Mostaganem, Naama, Retizane, Saida, Tiaret, Tlemcen and Tissemsilt).

\section{Criteria for diagnosis}

Only patients whose definitive diagnosis was made in the paediatric oncology department by a symptomatic clinical examination of more or less complete insufficiency (Anaemic syndrome and/or infectious syndrome and/or syndrome hemorrhagic) with or without tumour syndrome (splenomegaly, hepatomegaly, lymphadenopathy, gingival hypertrophy, bone pain) and paraclinical examination with specimens in the laboratory haematology based on biological and/or histological examinations: the blood count, morphological examination of blood smears, and a study of the medullogram (a medullar blast cell count $\geq 20 \%$ ). However, patients benefit from cytometric confirmation by flow cytometry (CMF).

\section{Data collection}

For the collection of data, we used the medical file of the patient, to fill out a record of exploitation which aims to specify the epidemiological, clinical, biological and evolutionary aspects of each patient admitted for AL. The parameters on which our study focused are:

1. Age, sex, usual residence and anthropometric parameters (height, weight, BMI).

2. Clinical information that pertains to antecedents (family, inbreeding between parents and personal history), reason for consultation, consultation time and symptoms.

3. Radiological data: Chest X-ray and abdominal ultrasound.

4. Biological data they concern:

a. The hemogram

b. Peripheral blood smear (blood film)

c. Biochemical assessment

d. Assessment of haemostasis

e. Medullogram

f. Lumbar puncture (LP)

g. Flow cytometry

5. Therapeutic aspects:

a. Start date of treatment induction

b. Evaluation date with the result of the medullogram exam

6. Evolutionary aspects: Remission, Relapse, Death, Lost of sight.

\section{Statistical analyzes}

The statistical analysis is based on the use of the SPSS 22 software (Statistical Package for the Social Sciences, IBM Corporation, Chicago, IL, August 2013). Quantitative variables by groups were compared by Student's " $t$ " test. Only significant differences at the $5 \%$ level were retained. Whereas, the Chi-square test was used for studying qualitative variables.

\section{RESULTS}

During the study period, 135 cases of diagnosed LA were identified (96 ALL and 39 AML), the sex ratio M/F in all participants was 1.1. The two to five-year age group was the most affected in both males and females (table 1). However, no significant differences were revealed between the two genders regarding all the studied parameters (age, anthropometric parameters, family history and consanguinity).

The comparison of clinical parameters between ALL and AML are summarized in table 2. As sign of spinal cord impairment, the infectious syndrome was significantly higher in ALL $(p<0.001)$ comparing to AML patients. Furthermore, regarding the tumor syndrome, the splenomegaly ( $p=0.002$ ) and the inguinal lymphadenopathy ( $p=0.044)$ were significantly frequent in ALL comparing to AML. No case of monocytic anemia has been recorded in AML group. However, higher significant positive $(p=0.045)$ cytochemical staining was recorded in AML patients. 
Table 3 highlight the comparison of biochemical parameters between the groups. Higher significant rates of lymphocytes and platelets were observed in ALL patients $(p=0.031$ and $p=0.026$, respectively) comparing to higher levels of neutrophils $(p=0.002)$ and MCH $(p=0.013)$ in AML patients. As a very important parameter, the blast rate was significantly higher in ALL comparing to AML patients $(p<0.001)$.
We also evaluated progressive aspect of the disease (presence of blasts, risk, clinical remission, loss of sight and death) in our study patients (table 4). Low rates of blats were observed in the two groups. The risk was higher in both ALL and AML with no significant difference. The loss of follow-up frequency was low in the two patients' groups. However, the general rate of death was about $11 \%$ in the both ALL and AML patients.

Table 1: Basic characteristics of participants

\begin{tabular}{|c|c|c|c|c|}
\hline & All patients $(n=135)$ & Males (n=72) & Females $(n=63)$ & $p$ value $*$ \\
\hline Age (years), mean \pm SD & $6.20 \pm 3.99$ & $6.24 \pm 4.19$ & $6.16 \pm 3.78$ & 0.912 \\
\hline Weight $(\mathrm{kg})$, mean \pm SD & $20.10 \pm 10.67$ & $20.59 \pm 11.48$ & $19.52 \pm 9.71$ & 0.563 \\
\hline High $(\mathrm{cm})$, mean \pm SD & $103.63 \pm 23.23$ & $104.32 \pm 24.86$ & $102.83 \pm 21.39$ & 0.711 \\
\hline \multicolumn{5}{|l|}{ Age group (years), n (\%) } \\
\hline$\leq 2$ & $20(14.8)$ & $11(8.1)$ & $9(6.7)$ & \multirow{4}{*}{0.274} \\
\hline$>2$ and $\leq 5$ & $51(37.8)$ & $28(20.7)$ & $23(17.0)$ & \\
\hline$>5$ and $\leq 12$ & $49(36.3)$ & $22(16.3)$ & $27(20.0)$ & \\
\hline$>12$ & $15(11.1)$ & $11(8.1)$ & $4(3.0)$ & \\
\hline \multicolumn{5}{|c|}{ Type of leukaemia, n (\%) } \\
\hline ALL & $96(71.1)$ & $48(35.6)$ & $48(35.6)$ & \multirow{2}{*}{0.223} \\
\hline AML & $39(28.9)$ & $24(17.8)$ & $15(11.1)$ & \\
\hline \multicolumn{5}{|l|}{ Family history, n (\%) } \\
\hline Yes & $15(11.9)$ & $9(6.7)$ & $6(4.4)$ & \multirow{2}{*}{0.583} \\
\hline No & $120(88.9)$ & $63(46.7)$ & $57(42.2)$ & \\
\hline \multicolumn{5}{|l|}{ Consanguinity, n (\%) } \\
\hline Yes & $27(20.0)$ & $13(9.6)$ & $14(10.4)$ & \multirow{2}{*}{0.546} \\
\hline No & $108(80.0)$ & $59(43.7)$ & $49(36.3)$ & \\
\hline
\end{tabular}

$(*)$ Comparison between males and females; mean values were compared using Student's $t$-test. Percentages were compared with Chi-square test, a $p<0.05$ was considered as significant; ALL: Acute Lymphoblastic Leukaemia; AML: Acute Myeloid Leukaemia. 
Table 2: Comparison of clinical parameters between ALL and AML

\begin{tabular}{|c|c|c|c|c|}
\hline & & ALL (n=96) & AML $(n=39)$ & $p$ value $*$ \\
\hline Signs of spinal cord impairmen & & & & \\
\hline Anemic sundrome & No & $6(4.4)$ & $1(0.7)$ & 0381 \\
\hline 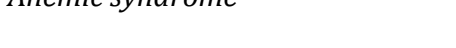 & Yes & $90(66.7)$ & $38(28.1)$ & 0.001 \\
\hline Infectious cundrome & No & $29(21.5)$ & $25(18.5)$ & $<0001$ \\
\hline 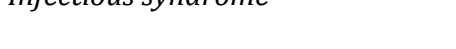 & Yes & $67(49.6)$ & $14(10.4)$ & -0.001 \\
\hline Hemorrhagic sundrome & No & $45(33.3)$ & $12(8.9)$ & 0086 \\
\hline & Yes & $51(37.8)$ & $27(20.0)$ & 0.000 \\
\hline Fever & No & $56(41.5)$ & $22(16.3)$ & 0838 \\
\hline 10ver & Yes & $40(29.6)$ & $17(12.6)$ & 0.000 \\
\hline Arthralaig & No & $61(45.2)$ & $25(18.5)$ & 0951 \\
\hline 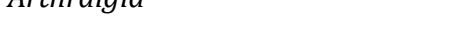 & Yes & $35(25.9)$ & $14(10.4)$ & 0.001 \\
\hline Asthenia & No & $40(29.6)$ & $13(9.6)$ & 0.369 \\
\hline 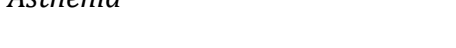 & Yes & $56(41.5)$ & $26(19.3)$ & 0.50 \\
\hline Paleness & No & $16(11.9)$ & $7(5.2)$ & 0857 \\
\hline 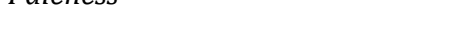 & Yes & $80(59.3)$ & $32(23.7)$ & 0.007 \\
\hline Tumor syndrome, $\mathrm{n}(\%)$ & & & & \\
\hline Splenomeaaly & No & $34(25.2)$ & $25(18.5)$ & 0.002 \\
\hline & Yes & $62(45.9)$ & $14(10.4)$ & \\
\hline Hepatomeaaly & No & $51(37.8)$ & $26(19.3)$ & 0.150 \\
\hline & Yes & 45 (33.3) & $13(9.6)$ & 0.150 \\
\hline Axillary lvmnhadenonathy & No & $59(43.7)$ & $30(22.2)$ & 0.086 \\
\hline 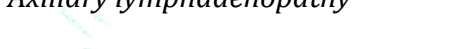 & Yes & 37 (27.4) & $9(6.7)$ & \\
\hline Inquinal lymphadenopathy & No & $59(43.7)$ & $31(23.0)$ & 0.044 \\
\hline & Yes & $37(27.4)$ & $8(5.9)$ & \\
\hline Corvical lymnhadenonathy & No & 45 (33.3) & $17(12.6)$ & 0728 \\
\hline 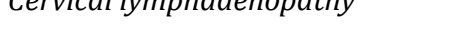 & Yes & $51(37.8)$ & $22(16.3)$ & 0.120 \\
\hline Ginaival lymnhadenonathy & No & 89 (65.9) & $36(26.7)$ & 0.936 \\
\hline 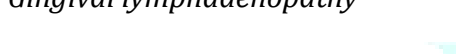 & Yes & $7(5.2)$ & $3(2.2)$ & \\
\hline Testicular lymphadenonathy & No & $96(71.1)$ & $38(28.1)$ & 0.115 \\
\hline & Yes & $0(0.0)$ & $1(0.7)$ & \\
\hline Cytopenia, n (\%) & - & & & \\
\hline Pancytopenia & No & $73(54.5)$ & $30(22.4)$ & 0.992 \\
\hline гапууцоретіла & Yes & $22(16.4)$ & $9(6.7)$ & 0.992 \\
\hline Bicytopenia & No & $32(23.9)$ & $10(7.5)$ & 0.362 \\
\hline Dicylopenta & Yes & $63(47.0)$ & $29(21.6)$ & \\
\hline Lеисосуtosis & No & $36(47.0)$ & $29(21.6)$ & 0362 \\
\hline 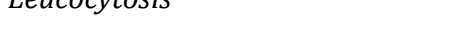 & Yes & $32(23.9)$ & $10(7.5)$ & 0.502 \\
\hline Anaemia type, n (\%) & & & & \\
\hline Macrocytic anaemia & & $10(7.5)$ & $0(0.0)$ & 0.035 \\
\hline Hypochromic microcytic anaemia & & $85(63.4)$ & $40(29.62)$ & \\
\hline Cytochemical staining, n (\%) & & & & \\
\hline Negative & & $96(71.1)$ & $13(9.6)$ & 0.045 \\
\hline positive & & $0(0.0)$ & $26(19.3)$ & $0.04 \mathrm{~J}$ \\
\hline
\end{tabular}

${ }^{*}$ ) Comparison between ALL: Acute Lymphoblastic Leukaemia; AML: Acute Myeloid Leukaemia using Chi-square test, a $p<0.05$ was considered as significant. 
Table 3: Comparison of biological parameters and blast rate between ALL and AML

\begin{tabular}{|c|c|c|c|}
\hline & ALL (n=96) & AML (n=39) & $p$ value ${ }^{*}$ \\
\hline White blood cells, $10^{3} / \mathrm{mm}^{3}$ & $34.75 \pm 5.47$ & $27.54 \pm 3.25$ & 0.443 \\
\hline Lymphocytes, $10^{3} / \mathrm{mm}^{3}$ & $19.29 \pm 2.72$ & $9.44 \pm 1.08$ & 0.031 \\
\hline Neutrophils, $10^{3} / \mathrm{mm}^{3}$ & $6.04 \pm 1.27$ & $16.64 \pm 2.56$ & 0.002 \\
\hline Red cells, $10^{6} / \mathrm{mm}^{3}$ & $2.76 \pm 0.73$ & $2.68 \pm 0.50$ & 0.491 \\
\hline Haemoglobin, g/dl & $8.02 \pm 1.97$ & $8.28 \pm 1.46$ & 0.449 \\
\hline Mean corpuscular volume, FL & $85.67 \pm 6.49$ & $86.27 \pm 12.15$ & 0.708 \\
\hline MCHC, g/dl & $33.75 \pm 2.72$ & $34.24 \pm 2.65$ & 0.350 \\
\hline $\mathrm{MCH}, \mathrm{gp}$ & $29.05 \pm 2.81$ & $30.47 \pm 3.30$ & 0.013 \\
\hline Platelet, $10^{3} / \mathrm{mm}^{3}$ & $67.93 \pm 7.94$ & $38.56 \pm 2.53$ & 0.026 \\
\hline Blast rate per myelogram, $\%$ & $83.92 \pm 1.68$ & $60.10 \pm 2.40$ & $<0.001$ \\
\hline
\end{tabular}

$(*)$ Comparison between ALL: Acute Lymphoblastic Leukaemia; AML: Acute Myeloid Leukaemia using Student $t$ test, a $p<0.05$ was considered as significant; MCHC: mean corpuscular hemoglobin concentration; MCH: mean corpuscular hemoglobin.

Table 4: Evolutionary characteristics for all participants between 2016 and 2018

\begin{tabular}{|c|c|c|c|}
\hline & ALL $(n=96)$ & AML $(n=39)(\%)$ & $p$ value ${ }^{*}$ \\
\hline \multicolumn{4}{|c|}{ Lumbar puncture, n (\%) } \\
\hline Normal & $95(70.4)$ & $38(28.1)$ & \multirow{2}{*}{0.507} \\
\hline Presence of blasts & $1(0.7)$ & $1(0.7)$ & \\
\hline \multicolumn{4}{|l|}{ Risk, n (\%) } \\
\hline Very high & $32(25.8)$ & $17(13.7)$ & \multirow{2}{*}{0.100} \\
\hline Moderate & $59(47.6)$ & $16(12.9)$ & \\
\hline \multicolumn{4}{|c|}{ Clinical remission, $\mathrm{n}(\%)$} \\
\hline No & $68(50.4)$ & $30(22.2)$ & \multirow{2}{*}{0.472} \\
\hline Yes & $28(20.7)$ & 9 (6.7) & \\
\hline \multicolumn{4}{|c|}{ Lost of follow-up, n (\%) } \\
\hline No & $95(70.4)$ & $36(26.7)$ & \multirow{2}{*}{0.039} \\
\hline Yes & $1(0.7)$ & $3(2.2)$ & \\
\hline \multicolumn{4}{|l|}{ Death, n (\%) } \\
\hline No & $80(59.3)$ & $24(17.8)$ & \multirow{2}{*}{0.006} \\
\hline Yes & $16(11.9)$ & $15(11.1)$ & \\
\hline
\end{tabular}

(*) Comparison between ALL: Acute Lymphoblastic Leukaemia; AML: Acute Myeloid Leukaemia using Chi-square test, a $p<0.05$ was considered as significant.

\section{DISCUSSION}

Data from the medical literature report that child's AL, although rare in itself, is the leading cause of pediatric cancer $(30 \%)$ and occurs mostly before the age of 9 years. In Europe and the United States, ALLs account for 75 to $80 \%$ of leukaemia and about $20 \%$ of cancers in children under 15 years of age. ${ }^{12}$ There are two main types of AL; ALL and AML.

In our series, 135 cases of children with AL were recorded during the period from January 2016 to December 2018. The distribution of ALL and AML and biphynotypic AL reveals a predominance of ALL with $60.45 \%$ of cases, followed by AML (23.88\%). The prevalence of biphynotypic leukaemia is in the order of $15.67 \%$. These results are in agreement with the statistics of the Ibn-Sina University Hospital Centre.10
We recorded a sex ratio $\mathrm{M} / \mathrm{F}$ of 1.1 vis-à-vis acute leukaemia (both types combined). This male dominance has also been observed in several other studies including the investigation of "frequency of childhood leukaemia in Qazvin province" and its correlation with sex, age and blood groups between 2006-2016 where sex ratio M/F was 1.24.13 Similarly, in 2016, Doumbia et al. noted the same observations with a sex ratio M/F of 1.08 (10). In contrariwise, Cumin et al. (1995) reported a sex ratio of 0.79 in favour of females. ${ }^{14}$

The age is an important prognostic factor; it is associated with poor progression when it is less than 1 year or older than 10 years. ${ }^{15}$ In the UK, the incidence is 30 per million children a year. This incidence is greatest between the age of 2 and 5 years. ${ }^{16}$ In France, the annual incidence is 137 per million children under 15 years of age. ${ }^{17}$ The highest rates are found in male children and children aged 1-4 years. ${ }^{18}$

CODEN (USA): JDDTAO 
In our study, the highest prevalence of AL was recorded for the 2- to 5-year and 5 to 12-year age groups with a predominance of ALL. Dargahi et al. (2016) reported the same results. ${ }^{13}$

The present study revealed that the duration between onset of symptom and diagnostic confirmation was about 50 days for ALL is almost 40 days for AML. This situation was described by Roganovic in 2013; "The symptoms can vary from a few days to a few months and often accumulate in a few days or weeks and result in an event that brings the child to medical attention." 19

In our case, most children had symptoms for 3-4 weeks. The symptoms and signs presented correlate with leukaemia cell load and the degree of bone marrow replacement, leading to cytopenia. The initial presentation includes the manifestations of the main clinical signs of bone marrow failure that have been reported by several studies.

According to Esparza \& Sakamoto (2005),20 common constitutional symptoms include fever (60\%), fatigue (50\%) and pallor $(25 \%)$. In our children, clinical signs were recorded in $90.4 \%$ of patients (94 cases) with fever in $61 \%$ of cases and hemorrhagic syndrome in $50 \%$ of cases. Anaemia at the time of diagnosis was present in most of our patients $(85 \%)$, which corroborates the findings of Pérez et al. (2018). ${ }^{21}$

However, the most common manifestations in our study were fever (55.8\%) and pallor (53.7\%). Hemorrhagic complications are common in patients with acute leukaemia (approximately 20\%).

Tumour syndrome is the result of the infiltration of different hematopoietic organs or even other organs by blast cells. It is more common in ALL than in AML resulting in hepatomegaly, splenomegaly, lymphadenopathy, bone pain, skin infiltrates and swollen gums. This syndrome was mainly present in our series in the form of adenopathies $163 \%$ of cases), splenomegaly was found in $56.30 \%$ of cases and hepatomegaly in $43 \%$ of cases. Bone involvement, which can manifest as spontaneous bone pain, was found in $36.30 \%$ of cases.

This situation is frequently encountered in other studies: in the study by Sall et al. (2015), splenomegaly was present in more than $75 \%$ of cases, associated with symmetrical lymphadenopathy rarely bulky while hepatomegaly was present in half of the cases. ${ }^{22}$ In their works, Acharya et al. (2018), ${ }^{23}$ hepatomegaly was the most common presentation (95\%), followed by splenomegaly (77\%), lymphadenopathy (58\%) and arthralgia (17.5\%).

Osteo-articular manifestations are an infrequent form of revelation of $\mathrm{AL}$ of the child, representing about $14 \%$ of cases, sometimes before the appearance of haematological signs. ${ }^{24}$

The hemogram which directs towards the diagnosis of the $\mathrm{AL}$, shows most often the attack of three lineages; white, red and platelet. It was performed in all patients in this study. Many studies show physiological variations in the blood count data. A high number of white blood cells (WBCs) (> $10,000 / \mathrm{mm}^{3}$ ) occurs in about half of the children, with $20 \%$ showing that the initial WBC level is greater than $50,000 / \mathrm{mm}^{3}$. Normochromic and normocytic anemia (hemoglobin $<10 \mathrm{~g} / \mathrm{dL}$ ) occurs in approximately $80 \%$ of children. Thrombocytopenia (platelet count $<100,000 /$ $\mathrm{mm}^{3}$ ) occurs in $75 \%$ of children at diagnosis. Spontaneous bleeding occurs in patients with less than 20,000-30,000 platelets $/ \mathrm{mm}^{3} .19$
In our series, 29 patients had a WBC rate greater than 50 $000 / \mathrm{mm}^{3}$, of which 20 cases $(76.3 \%)$ of ALL and 9 cases $(23.7 \%)$ of AML. Those with profound leukocytosis with neutropenia account for $82.9 \%$ of ALL and $17.1 \%$ of AML. The presence of anaemic syndrome with a haemoglobin level between 7 and $10 \mathrm{~g} / \mathrm{d}$ was recorded in $69 \%$ of ALL patients and $30.7 \%$ of AMLs.

The myelogram allows the diagnosis of AL when the marrow is invaded by at least $20 \%$ of abnormal blasts, in practice often more than $80 \%$ of AL. In our series, we found a highly significant difference $(p<0.001)$ between the two types of leukaemia with respect to blast content: in ALL (83.92 \pm $16.89 \%$ ) was significantly elevated compared to blast levels in AML $(60.10 \pm 24.05 \%)$. These results are similar to those of Doumbia et al. (2016).10

Immunophenotyping has become an essential step in the diagnosis of acute leukaemia, it makes it possible to confirm the cell line involved in the leukemic process, and to specify the blocking stage of blasts in their differentiation. ${ }^{25}$

Lumbar puncture examination was normal in the vast majority of cases for ALL (70\%) or AML (28.15\%) with a clear appearance. These findings were also reported by Mwirigi et al., 2017, who found leukemic infiltration of the central nervous system in less than $10 \%$ of patients with ALL. ${ }^{26}$

The treatment of childhood leukaemia has changed dramatically over the past 50 years. The overall cure rate is $80 \%$ with variations depending on the different AL subtypes. Several studies show results about the evolution of AL. During the course of our study, we recorded a complete remission in the vast majority of cases (51 cases), followed by relapses ( 28 cases) and death (16 cases) and we recorded a single case of lost sight. In parallel, 15 cases of death were recorded for AML leukaemia, 11 cases of complete remission and 9 cases of relapse. Several authors have noted nearly similar results. ${ }^{10,27}$

\section{CONCLUSIONS}

Our results reveal that LA in children in the west and southwest region of Algeria is increasing alarmingly. The characteristics of our population are similar to the data in the literature on clinical, biological and evolutionary levels without a specific unusual feature for our region. The management of this disease must bring together all stakeholders in public health professionals and must integrate the local and regional networks of pediatric cancer care. Indeed, the specificity of the care of children with cancer must build a national and an international strategy.

\section{Acknowledgements}

Our gratitude is addressed to all the staff of the institution in which our study was conducted for their constant and strong support.

\section{Conflict of Interest: No}

This article is distributed under the terms of the Creative Commons Attribution-NonCommercial 4.0 International License

(http://creativecommons.org/licenses/by-nc/4.0/), which permits any noncommercial use, distribution, and reproduction in any medium, provided you give appropriate credit to the original author(s) and the source, provide a link to the Creative Commons license, and indicate if changes were made 


\section{REFERENCES}

1. Guyot-Goubin A, Clavel J. Les hémopathies malignes. In: Épidémiologie des cancers de l'enfant, eds. Springer, Paris, 2009: 49-54.

2. Pommert L, Margossian S, Burke M, "Diagnosis and TreatmentRelated Complications of Acute Leukemia. In: Critical Care of the Pediatric Immunocompromised Hematology/Oncology Patient, eds. Springer, Boston, 2019: 9-27.

3. Braham-Jmili N, Sendi-Senana H, Khelif A, Saad A, “Leucémies aiguës myéloïdes en Tunisie : caractéristiques épidémiologiques et cliniques et classification OMS“J Afr Cancer, $2010 ; 2: 25-32$. https://doi.org/10.1007/s12558-010-0062-8.

4. Harioly Nirina MOM, Rakotoarivelo ZL, Ntoezara A, Rasolonjatovo AS, RakotoAlson AO, Rasamindrakotroka A, "Épidémiologie et diagnostic des leucémies aiguës à l'hôpital Ravoahangy Andrianavalona Antananarivo Madagascar" J Afr Cancer, 2015 ; 7:186-189. https://doi.org/10.1007/s12558-015-0393-6.

5. Donadieu J, Auclerc MF, Baruchel A, Leblanc T, Landman-Parker J, Perel Y, Michel G, Cornu G, Bordigoni P, Sommelet D, Leverger G, Hill C, Schaison G, "Critical study of prognostic factors in childhood acute lymphoblastic leukaemia: differences in outcome are poorly explained by the most significant prognostic variables" British Journal of Haematology, 1998; 102 (3):729739. https://doi.org/10.1046/j.1365-2141.1998.00818.x.

6. Petrov I, Suntsova M, Mutorova O, Sorokin M, Garazha A, Ilnitskaya E, Spirin P, Larin S, Kovalchuk O, Prassolov V, Zhavoronkov A, Roumiantsev A, Buzdin A, "Molecular pathway activation features of pediatric acute myeloid leukemia (AML) and acute lymphoblast leukemia (ALL) cells" Aging (Albany NY), 2016; 8(11):2936-2947. doi: 10.18632/aging.101102.

7. Sabbah L. Leucémies aiguës. In: Mega guide stages IFSI, eds. Elsevier Masson. 2nd ed. Paris, 2015: 121-125.

8. Belson M, Kingsley B, Holmes A, "Risk factors for acute leukemia in children: a review", Environ Health Perspect, 2007;115(1):138-145.

9. Abdul Hamid G. Acute Leukemia Clinical Presentation. In: LEUKEMIA, eds. InTech. Croatia, 2013: 75-97.

10. Doumbia M, Uwingabiye J, Bissan A, Rachid R, Benkirane S, Masrar A, "Aspects épidémiologiques, cliniques, cytologiques et immunophénotypiques des leucémies aiguës chez les enfants : expérience du laboratoire d'hématologie du Centre Hospitalier Universitaire IBN Sina" Pan Afr Med J, 2016; 23:258.

11. Preudhome $\mathrm{C}$, "Biologie moléculaire et leucémies aiguës" Revue Française des Laboratoires, 2002 ; 2002(344):41-46.

12. Coebergh JW, Reedijk AM, de Vries E, Martos C, Jakab Z, Steliarova-Foucher E, Kamps WA, "Leukaemia incidence and survival in children and adolescents in Europe during 19781997. Report from the Automated Childhood Cancer Information System project" Eur J Cancer, 2006 42(13):20192036.

13. Dargahi T, Goudarzi M, MobarraN, Poorkarim H, Rahmani S, Khalili M, Amini M, Hamedani J, Azad M, "Investigation of Leukemia Frequency in Children of Qazvin Province and its
Correlation with Gender, Age, and Blood Groups between 20062016" Novel Biomed, 2016; 4(4):135-141. https://doi.org/10.22037/nbm.v4i4.14670.

14. Cumin I, Mechinaud-Lacroix F, Avet-Loiseau H, Fischer A, Harousseau JL, "Leucémies aiguës néonatales: à propos de sept observations" Archives de Pédiatrie, 1995; 2(11): 1060-1066. https://doi.org/10.1016/0929-693X(96)81281-4.

15. Kaldor JM, Day NE, Clarke EA, Van Leeuwen FE, Henry-Amar $\mathrm{M}$, Fiorentino MV, et al. Leukemia following Hodgkin's disease. $N$ Engl J Med, 1990; 322(1):7-13. doi: 10.1056/NEJM199001043220102.

16. Lanzkowsky P. Leukemias. In: Manual of Pediatric Hematology and Oncology, eds. Elsevier. 4th ed. London, 2005:415-452.

17. Perel Y. Cancers et leucémies de l'enfant et de l'adolescent. In: Pédiatrie, eds. Elsevier Masson. 6th ed. Paris, 2011: 419-426.

18. Barrington-Trimis JL, Cockburn M, Metayer C, Gauderman WJ, Wiemels J, McKean-Cowdin R, "Trends in childhood leukemia incidence over two decades from 1992 to 2013" Int J Cancer, 2017; 140(5): 1000-1008. doi: 10.1002/ijc.30487.

19. Roganovic J. Acute Leukemia Clinical Presentation. In: LEUKEMIA, eds. InTech. Croatia, 2013: 39-74.

20. Esparza SD, Sakamoto KM, "Topics in pediatric leukemia--acute lymphoblastic leukemia" Med Gen Med, 2005; 7(1):23.

21. Jaime-Pérez JC, García-Arellano G, Herrera-Garza JL, MarfilRivera LJ, Gómez-Almaguer D, "Revisiting the complete blood count and clinical findings at diagnosis of childhood acute lymphoblastic leukemia: 10-year experience at a single center" Hematol Transfus Cell Ther, 2019; 41(1): 57-61. DOI: 10.1016/j.htct.2018.05.010.

22. Sall A, Sène A, Djiba B, Diallo M, Faye BF, Seck M, Gadji M, Dièye TND, Touré AO, Diop S, Raphaël M, “Leucémie prolymphocytaire T: à propos d'une observation et revue de la littérature" J Afr Cancer, 2015 ; 7:236-239. https://doi.org/10.1007/s12558015-0388-3.

23. Acharya S, Maiti D, Datta S, "Clinico-epidemiological study of extramedullary disease manifestations in childhood acute lymphoblastic leukaemia in a tertiary care centre" Int J Contemp Pediatr, 2018; 5(4):1637-1640. DOI: http://dx.doi.org/10.18203/2349-3291.ijcp20182580.

24. Flatrès C, Pennanéach A, Blondin G, Rivoal E, Haro S, Vic $P$, "Leucémie aiguë découverte par imagerie par résonance magnétique osseuse : deux observations pédiatriques" Archives de Pédiatrie, 2017; 24(6):542-546. https://doi.org/10.1016/j.arcped.2017.03.015.

25. Béné MC, Lacombe F, "Place de la cytométrie en flux dans le diagnostic et le suivi des leucémies aiguës" Revue Francophone des Laboratoires, 2015; 2015(471):35-41.

26. Mwirigi A, Dillon R, Raj K, "Acute leukaemia" Medicine, 2017; 45(5):280-286.

27. Lahlou Z, Lafhel I, Maani K, Hachim J, Itri A, "Leucémies aigues de l'enfant : Etude de 142 cas" Archives de Pédiatrie, 2014; 21(5)supp1:357. https://doi.org/10.1016/S0929693X(14)71617-3. 